\title{
A REFORMA DA PREVIDÊNCIA E SEUS ASPECTOS JURÍDICOS, SOCIAIS E ECONÔMICOS
}

\section{THE SOCIAL SECURITY REFORM AND ITS LEGAL, SOCIAL AND ECONOMIC ASPECTS}

\author{
${ }^{1}$ Jonas Albert Schmidt
}

\section{RESUMO}

A Previdência Social no Brasil, assim como em outros países, é uma das maiores Políticas Sociais existentes e possui enorme capacidade de criar reservas financeiras para seu financiamento e, consequentemente a diminuição das desigualdades sociais. Entretanto, por esse mesmo motivo, de ser capaz de captar recursos pelos Estados, torna-se alvo de especulações, em que o mercado e os próprios governos utilizam-se de manobras ideológicas para desmantelar direitos garantidos constitucionalmente para transferir, no todo ou em parte, a proteção que deveria partir do Estado para tornar-se mercadoria livremente negociável no mercado financeiro mundial.

Palavras Chaves: Previdência Social. Contrarreforma. Direitos Sociais. Privatização. Capitalismo.

\begin{abstract}
Social Security in Brazil, as in other countries is one of the largest existing and Social Policy has enormous capacity to create financial reserves for funding and consequently the reduction of social inequalities. However, for that very reason of being able to raise funds by States to become the target of speculation, the market and governments themselves uses maneuvers to dismantle ideological vested and constitutionally guaranteed to transfer in whole or in part, protection that should leave the state to become freely tradable commodity in the global financial market.
\end{abstract}

\footnotetext{
${ }^{1}$ Advogado Previdenciarista, Especialista em Direito Administrativo pela, Escola Superior - Ministério Público - Mato Grosso, ESMP/MT, (Brasil). Mestre em Política Social pela Universidade Federal de Mato Grosso - UFMT, Mato Grosso, (Brasil). Com intercâmbio na Universidade de Coimbra/Portugal, Vice-Presidente (2016-2018) da Comissão de Direito Previdenciário da OAB/MT. E-mail: jonasalbert@ hotmail.com
} 
Keywords: Social Security. Counter-reformation. Social Rights. privatization. Capitalism.

\section{INTRODUÇÃO}

Desde meados da década de 1990, tiveram início no Brasil as reestruturações da seguridade social na contramão dos direitos até então conquistados. Em vista disso, objetivamos, com este artigo, demonstrar o pano de fundo econômico que sustenta as reformas da previdência ocorridas desse a década de 1990, em especial no setor público, agora pautadas para os trabalhadores da iniciativa privada. Contudo, utilizou-se o método hipotético-dedutivo partindo da análise histórica na implementação da seguridade social no Brasil com a Constituinte de 1988. Foram analisadas a legislação infraconstitucional em vigor tendo como partida as normas contidas na própria Constituição em seu texto original, quando da sua promulgação em 05 de outubro de 1988, e posteriores emendas.

Portanto, as operações legislativas da década de 1990, quando foi regulamentada a nova Constituição, já sinalizavam a retirada estratégica do Estado das obrigações sociais e legavam ao capital financeiro a especulação dos fundos de pensão que nos países de capitalismo central já eram uma realidade. Iniciou-se então o que chamamos de contrarreforma que são "reformas orientadas para o mercado, num contexto em que os problemas no âmbito do Estado brasileiro eram apontados como causas centrais da profunda crise econômica e social vivida pelo país desde o início dos anos 1980", conforme observam Behring e Boschetti (2007, p.148), fenômeno este que retira e/ou modifica direitos trabalhistas e previdenciários.

Naquele contexto, e nos desdobramentos que se seguiram nos últimos e no atual governo, o país tomou medidas restritivas de direitos, alegando serem necessárias à contenção de um questionável déficit previdenciário. Portanto, essas ações de enfrentamento oferecidas nas gestões dos governos federais, fragilizaram conquistas históricas dos trabalhadores e se materializam na aprovação de leis que dilapidam estes avanços sociais, sendo legitimadas por meio de discursos no sentido de convencer a população de uma real e urgente necessidade de reformar a previdência. É importante destacar que no Brasil, com a redemocratização da 
década de 1980, o novo pacto foi formado com a Constituinte de 1988, em que direitos sociais foram introduzidos na ordem constitucional, fazendo parte, portanto, de uma nova agenda nacional.

Há um arcabouço discursivo para convencer a população em relação a tais medidas de austeridade social. Vale lembrar que as medidas de austeridade contra a previdência vêm sendo tomadas por diversos governos de partidos distintos, mostrando a inclinação do Brasil às políticas macroeconômicas de cunho liberal, ainda que vestidas numa roupagem socialdemocrata. Em texto publicado pelo extinto Ministério da Previdência, por meio da Secretaria de Previdência Social em 2003, ano em que foi publicada a Emenda à Constituição n. 41, já no primeiro ano do Governo de Luiz Inácio Lula da Silva, no desdobramento da reforma iniciada em 1998, ainda no Governo de Fernando Henrique Cardoso, o técnico do IPEA - Instituto de Pesquisa Econômica Aplicada, Ricardo Varsano (2003, p. 7), afirma que:

A reforma dos sistemas previdenciários é um item importante da agenda internacional. As elevadas contribuições sobre a folha de salários, comumente usadas para financiar os sistemas, além de afetarem a competitividade, criam uma cunha entre o custo do trabalhador para as empresas e o salário que eles recebem. Com isto, estimulam a informalização das relações trabalhistas - ou, até mesmo, afetam o nível de emprego -, o que, por seu turno, reduz a própria base desses tributos.

Uma solução possível para a questão é limitar a proteção oferecida pelos Estados ao trabalhador, viabilizando a redução dos tributos que incidem sobre os salários. O caminho alternativo é preservar os benefícios e buscar fontes de financiamento que substituam total ou parcialmente a base tradicional.

É evidente, no discurso apresentado à população em 2003, o intuito de responsabilizar o trabalhador pela sua proteção, indicando a incapacidade estatal para financiar o sistema e, ainda, o "custo empresarial" que as políticas sociais causam, afetando diretamente os índices de empregabilidade, mais uma vez responsabilizando o próprio trabalhador pela informalidade nas relações trabalhistas. Este discurso não se mantém na medida em que, conforme afirmado por Varela (2012), o custo do Estado Social é pago pelo próprio trabalhador, tendo em vista que as contribuições previdenciárias são consideradas pelos empresários como "custo de folha", portanto, é embutido no preço final de seus produtos, os 
quais são consumidos, então, pelos trabalhadores. Dessa forma, como lembra a historiadora portuguesa, o Estado Social é pago por quem é beneficiado por ele.

No entanto, o orçamento da Seguridade Social sempre foi tema polêmico nas agendas dos Estados, na medida em que o financiamento da proteção social e erradicação da pobreza, conforme prevê a Constituição brasileira, vai de encontro aos interesses do mercado, portanto, é assunto polemizado e constantemente atacado com inverdades. No Brasil, onde a população é carente de tudo, até de informações, o discurso desmoralizador e enfraquecedor da Previdência Social é facilmente disseminado na maior parte da população.

\begin{abstract}
Nos anos 1990, uma seguridade generosa e igualitária, inspirada no sistema de proteção social europeu entrara em conflito com a perspectiva liberalconservadora que então se tornara dominante no Brasil e num mundo de economias abertas, desreguladas e ferozmente competitivas. O nascimento do sistema de seguridade social brasileiro, através da Constituição Federal de 1988, foi marcado pela fragmentação e descaracterização que esse momento histórico impôs, quando as teses politicas conservadoras dos grupos que se uniam em torno do modelo liberal reuniram forças no início dos anos 1990 no cenário politico nacional. (GENTIL, 2006, p. 20)
\end{abstract}

Contudo, para entender o cenário em que tais reformas se apresentam, e também, as estratégias legislativas utlizadas para convencimento da população das urgentes reformas, ou melhor dizendo, da reforma inconclusa, como afirma Silva (2008), os mecanismos são pontuais, ou seja, retirada estratégica de direitos, imposição ao trabalhador para lançar mão nos planos privados e restrição na concessão de benefícios.

Com essa finalidade, tramitava no Congresso Nacional o Projeto de Lei n. 1.992/2007, que tratava da previdência complementar dos servidores públicos federais, o qual converteuse na Lei Federal n. 12.618, de 30 de abril de 2012. Vale lembrar que as reformas que atingem os servidores públicos federais, por força constitucional do art. $40, \S 12$, estendem-se a todos os servidores públicos das demais esferas de poder. Portanto, a implantação do teto não atingiu somente os servidores da União, passou a valer também para os Estados e Municípios, que optassem por implementar tal regime. Entretanto, a lei complementar em comento prevê, no parágrafo único do art. $1^{\circ}$, que será oferecido ao segurado já ingresso no serviço público, até a publicação da nova legislação, a opção em aderir ou não ao regime de previdência 
complementar. Com a nova lei, o objetivo pontual daquele governo era a implementação do teto para pagamento de benefícios, mas para isso havia a necessidade de se cumprir o dispositivo constitucional que exigia a prévia criação da previdência complementar nos termos do parágrafo 14 do art. 40 da Constituição Federal:

$\S 14$ - A União, os Estados, o Distrito Federal e os Municípios, desde que instituam regime de previdência complementar para os seus respectivos servidores titulares de cargo efetivo, poderão fixar, para o valor das aposentadorias e pensões a serem concedidas pelo regime de que trata este artigo, o limite máximo estabelecido para os benefícios do regime geral de previdência social de que trata 0 art. 201.

Portanto, ao criar um regime complementar, ainda que de cunho facultativo, o Estado estará favorecendo a iniciativa privada ao abrir as portas destes fundos públicos para os bancos e instituições financeiras. É nesta perspectiva que o governo federal trabalha. São sinais da privatização da previdência brasileira, a exemplo do que ocorreu no Chile e na Argentina ainda na década de 1980. Contudo, uma vez estipulado o teto para pagamento dos benefícios aos segurados do regime próprio da União, logo, dos Estados e Municípios, obrigar-se-á grande parcela dos servidores a migrar para o novo sistema de caráter especulativo.

A previdência complementar, de natureza privada, já prevista na primeira reforma em 15 de dezembro de 1998, com a EC 20/98, ao ser efetivamente implantada no setor público significa que, ao requerer sua aposentadoria, o trabalhador não receberá valor superior ao limite imposto pela norma, cabendo-lhe, caso queira proventos de inatividade semelhantes aos rendimentos salariais do período de atividade, contribuir para um sistema paralelo de natureza complementar.

Desta forma, o governo da presidente Dilma Rousseff objetivou primeiramente a criação dos regimes complementares, projeto iniciado pelo presidente que lhe antecedeu, para justificar e cumprir os ditames constitucionais para então impor o teto para os benefícios, complementando assim o projeto reformista dos governos anteriores e do atual.

Art. 40 (redação dada pela EC 20/98)

$\S 14$ - A União, os Estados, o Distrito Federal e os Municípios, desde que instituam regime de previdência complementar para os seus respectivos servidores titulares de cargo efetivo, poderão fixar, para o valor das 
aposentadorias e pensões a serem concedidas pelo regime de que trata este artigo, o limite máximo estabelecido para os benefícios do regime geral de previdência social de que trata $\mathrm{o}$ art. 201.

$\S 15$ - Observado o disposto no art. 202, lei complementar disporá sobre as normas gerais para a instituição de regime de previdência complementar pela União, Estados, Distrito Federal e Municípios, para atender aos seus respectivos servidores titulares de cargo efetivo.

$\S 16$ - Somente mediante sua prévia e expressa opção, o disposto nos $\S \S 14$ e 15 poderá ser aplicado ao servidor que tiver ingressado no serviço público até a data da publicação do ato de instituição do correspondente regime de previdência complementar.

Para compreendermos melhor esta situação, a Emenda Constitucional n. 20/98 já estipulava a criação de um regime complementar em que o fundo de previdência poderia então limitar o pagamento dos benefícios dos servidores, ou seja, adotar no Regime Próprio de Previdência Social - RPPS os mesmos critérios do Regime Geral de Previdência Social RGPS. Aquele regime não possuía, até o presente momento, teto para pagamento de seus benefícios e tampouco teto para o recolhimento das contribuições dos servidores. Contudo, o teto vigente no RGPS era utilizado tão somente para balizar o pagamento de pensões por morte dos servidores públicos, o que provoca uma redução de 30\% (trinta por cento) dos valores que ultrapassam o teto, conforme reza o art. $40, \S 7^{\circ}$, I e II da Constituição Federal.

O teto do RGPS é também responsável para definir as contribuições, ou bis in idem², dos inativos impostas na Lei Federal n. 10.887/2004, de 18 de junho de 2004. Desta forma, todo servidor público aposentado, na regra atual, continuará sendo contribuinte do sistema quando seus proventos de inatividade ultrapassarem o teto estipulado no regime geral. Com isso, os governistas, nas três esferas, fazem gestão no sentido de ajustar a legislação que determina o teto e que, consequentemente, beneficia os fundos de pensão privados, visto que à luz da lógica economicista isto desonerará os regimes previdenciários públicos.

Havia, sem dúvida, grande interesse de organismos privados, principalmente de instituições financeiras, em que os fundos de pensões ou previdência complementar fossem regulamentados, pois os valores oriundos das contribuições dos servidores migrarão fatalmente para o mercado especulativo e ficarão sob o domínio dos bancos e financeiras.

\footnotetext{
${ }^{2}$ Quando ocorre uma tributação mais de uma vez sobre o mesmo sujeito passivo sobre o mesmo fato gerador.
} 
Quanto à gestão desses fundos de pensão, ainda que sejam de ordem colegiada por meio de conselhos deliberativos como é feito atualmente com os regimes próprio e geral, conceder-seá novo nicho de mercado aos especuladores. É a institucionalização, ainda que parcial, da privatização da previdência pública.

Em análise do sítio da ABRAPP - Associação brasileira das entidades fechadas de previdência complementar, é possível colher dados importantes que indicam a força que os fundos de pensão possuem não somente no Brasil, mas no mundo, e que garantem altas taxas de lucratividade ao mercado financeiro à custa das contribuições do trabalhador. $\mathrm{O}$ "postulado" da entidade, refere-se à previdência de natureza privada como sendo obrigação do Estado o seu estímulo numa perspectiva clara de o capital utilizar-se, inclusive, de recursos públicos:

\begin{abstract}
A Previdência Social é um direito do cidadão e dever da sociedade, tem caráter universal e independe da capacidade contributiva do segurado. A Previdência Complementar Privada deve ser acessível a todos, competindo ao Estado apoiá-la e estimulá-la. A Previdência Complementar Privada visa a preservar a promoção social conquistada pelo trabalhador e representa um avanço nas políticas de recursos humanos das empresas, sob o regime da democracia econômica. O Fundo de Pensão, fruto da livre iniciativa inerente às sociedades democráticas, é uma entidade de direito privado com caráter e finalidade social. Organizado sob o regime de capitalização, ideal e insubstituível para a consecução dos seus fins sociais, ao Fundo de Pensão deve ser assegurada ampla liberdade de escolha das oportunidades de mercado na aplicação das suas reservas. Como instituição social, responsável ante as demais instituições e o País, o Fundo de Pensão acha-se indeclinavelmente subordinado à ética e à transparência em todos os seus atos.
\end{abstract}

Como podemos ver, a reforma estratégica da previdência social no Brasil começou com o funcionalismo público, sendo que o alvo atual é, também, os trabalhadores do setor privado, os quais serão, segundo o governo, os principais atingidos pelas novas regras de aposentadoria.

\title{
2 O PACTO INTERGERACIONAL E AS POLÍTICAS ECONÔMICAS
}


Atualmente estão em voga expressões como explosão demográfica, aumento da expectativa de vida e envelhecimento populacional. No entanto, além da falsa perspectiva de um déficit nas contas da previdência, como veremos, outro argumento muito utilizado é de que a repartição simples e o pacto intergeracional também causam déficit no sistema. Dessa forma, mudou-se a legislação para a criação de regimes complementares para os servidores, os quais são de capitalização individual, e orienta-se a adesão aos fundos privados. O Banco Mundial e o Fundo Monetário Internacional estimulavam tal prática, ainda na década de 1990, como nos ensina Leda Maria Paulani (2008), não somente nos países subdesenvolvidos, mas também, nos países ricos, na medida em que a capitalização dos fundos de pensão públicos, em especial, contribui para a financeirização do capital e direciona para a total privatização destas carteiras financeiras, as quais são de grande interesse do mercado especulativo.

Ao passo que os sistemas de repartição simples, fruto dos sistemas de proteção oriundos do Welfare State, garantem a atuação do Estado no que diz respeito ao financiamento da proteção do trabalhador, portanto, a previdência como um direito de cidadania e não como um direito de contribuinte, conforme leciona Paulani (2008). O sistema de repartição simples, proveniente da história nos períodos de construção de direitos sociais, principalmente no período caracterizado pelo keynesianismo, entre o segundo pós-guerra e meados da década de 1970, é caracterizado por princípios, segundo a mesma autora (2008, p. 25):

Três princípios básicos caracterizam esse regime previdenciário, conhecido por regime de repartição simples e que tem no sistema previdenciário público seu instrumento de atuação: a universalidade do benefício, a participação do Estado dentro do esquema tripartite de sustentação financeira (empregados, empregadores e Estado) e a solidariedade intergeracional [...] Todos esses princípios estão ligados entre si e conformam uma dinâmica que é impulsionadora do crescimento e joga do lado da valorização produtiva do capital e da distribuição de renda.

Dessa forma, explica, no sistema de repartição simples, quanto maior for a empregabilidade e a renda, maior será o equilíbrio financeiro e atuarial, portanto, não haveria déficit. Ocorrendo o contrário, seria inevitável o déficit nas contas da previdência, tendo em 
vista a baixa participação dos trabalhadores. Em relação ao segundo sistema, o de capitalização, a autora nos remete aos regimes herdados das associações mutualistas, as quais foram criadas para categorias específicas de profissionais.

De caráter privado e restrito, o regime reforça o vínculo entre contribuições e benefício e, contrariamente ao sistema anterior, joga contra o crescimento econômico e ao lado da valorização financeira. Seus instrumentos de operação são os fundos de pensão, fechados ou abertos [...] Lastreados em papéis públicos, eles têm, portanto, todo o interesse na manutenção de elevadas taxas reais de juros ao invés de em baixas taxas. Possuindo ações e debêntures, eles jogam ao lado de salários deprimidos e políticas de downsizing [...] (PAULANI, 2008, p. 24)

Essa solidariedade invertida amarra a garantia dos benefícios futuros à penúria do presente em termos de emprego e salário. Esse sistema evidente nos fundos de pensões privados, oferecidos e gerenciados exclusivamente pelas instituições financeiras, públicas ou privadas, também se caracteriza em regimes previdenciários públicos, como são os casos dos fundos de previdência dos servidores estatais e municipais. Como já mencionado anteriormente, na década de 1990 começaram os ataques ao sistema previdenciário brasileiro, após a consolidação dos direitos sociais na constituinte de 1988. A maior investida da política neoliberal da época ocorreu com a promulgação da Emenda à Constituição n. 20/1998, que estabeleceu regras para as aposentadorias dos servidores públicos, modificando o texto do art. 40 da Carta Magna e, acima de tudo, estimulou a criação e manutenção dos regimes próprios, numa formatação de sistema de capitalização individual, tal como os sistemas privados.

Esse sistema que atualmente alcança mais de 2.000 municípios, todos os Estados da Federação e a própria União, segundo dados estatísticos de $2015^{3}$, possui um patrimônio acumulado de cerca de $\mathrm{R} \$ 175$ bilhões. É importante esclarecer que, ao criar um regime próprio, não se trata de atuação do Estado enquanto provedor fiscal dos benefícios, ao contrário, o Estado ou município neste momento é empregador e cumpre com suas obrigações contratuais nesta relação trabalhista. As receitas que compõem os regimes próprios são oriundas das contribuições sociais dos servidores e de seus respectivos empregadores (entes

Disponível em: http://www.previdencia.gov.br/2015/07/regimes-proprios-ministerio-estabelece-novosrequisitos-para-classificar-rpps-como-investidores-qualificados-ou-profissionais/. Acessado em 23 set. 2016. 
públicos). Mesmo que a receita provenha dos impostos indiretos, o trabalhador público fica desprotegido, ao passo que, se perder o vínculo, ou mesmo se estiver afastado temporariamente, deixa de ter cobertura aos riscos de sua existência. Essa forma individualizada de proteção, em que se coloca nas mãos do trabalhador a responsabilidade de suas garantias presentes e futuras, fica ainda mais caracterizada em situações em que o servidor público, ao pedir afastamento de suas atividades, sem, contudo, perder o vínculo funcional, para manter a qualidade de segurado do regime em que é filiado, deverá fazer o pagamento mensal de suas contribuições e, inclusive, arcar com a quota patronal, já que a obrigação do Estado ou município é meramente contratual, na qualidade de empregador. Portanto, há essa diferença fundamental entre a característica de um Estado provedor e aquelas situações em que a proteção ocorre em detrimento de um contrato de obrigações laborativas, no presente caso, a relação existente entre os trabalhadores do setor público e o ente estatal.

Contudo, é possível compreender melhor os ataques que são feitos ao sistema previdenciário público, de repartição simples e solidariedade intergeracional, pois, como mencionado, é um sistema que caminha ao lado do desenvolvimento econômico e social, com garantias de emprego e renda para a população. Essas críticas e afirmações ideológicas de um déficit previdenciário no Brasil não são feitas por acaso, certamente, já que são de interesse do mercado especulativo os fundos de pensão, de caráter privado ou público, mas que sejam de capitalização, já que lucram duas vezes, seja na especulação financeira que fazem nas carteiras destes fundos, seja na própria essência dos mesmos, já que retiram obrigações do Estado, enquanto provedor, desonerando-o e, portanto, sobrando mais recursos para o capital.

São, portanto, os cortes nos direitos sociais, impostos pelos planos de austeridade, os primeiros a serem atingidos. Assim, “com o regime de repartição simples, a previdência joga no sentido de redução de taxas de juros e da elevação dos níveis de crescimento, emprego e renda" (PAULANI, 2008, p. 25). Com isso, as altas taxas de juros, como eram comuns na década de 1990, a investida do capital é no sentido de especular e lucrar de forma desenfreada à custa do sofrimento e subdesenvolvimento do povo. Paulani (2008, p. 25) ainda afirma que “o regime de capitalização é pior que pró-cíclico, pois ele é neutro quando a maré é favorável, mas joga completamente contra, quando os ventos empurram a economia ladeira abaixo". 
A situação se agrava ao passo que esses fundos públicos de previdência social são constantemente alvos de especulação financeira pelo mercado e até mesmo pelos governos. Esse sistema de capitalização individual é regulamentado por legislação federal, portanto, tem um alto controle em nível nacional. São formados regimes próprios de previdência social, desvinculados do regime geral e gerenciados pelos municípios e Estados membros. Exige-se que se alcance meta atuarial anual, atualmente em $6 \%$ mais os índices da inflação. Ocorre que o lastramento desses fundos é feito por meio de títulos públicos federais, ações nas bolsas de valores e demais "mercadorias" oferecidas pelos bancos.

O Banco Mundial ${ }^{4}$ em 1994, por meio do relatório Averting the Old Age Crisis já mencionava o interesse do capital nesses fundos de pensão, comentava, portanto, sobre a crise pela qual o sistema público de previdência passava, mencionava o envelhecimento da população, dando exemplos em diversos países da Europa, América latina e África. Contudo, apoiava esse relatório na necessidade de se operar com múltiplos sistemas, incluindo certamente o privado por meio do estímulo à poupança individual. Essa orientação não estava direcionada apenas aos países subdesenvolvidos do hemisfério sul, mas incluía até mesmo os nórdicos. Daí o discurso do desequilíbrio financeiro dos sistemas públicos de previdência social. Os países mergulhados em políticas neoliberais "compraram" essa ideia e reformaram seus sistemas, precarizando-os, além, é claro, de manipular a opinião popular sobre o déficit nas contas públicas.

Em casos mais drásticos, como na Argentina, houve a total privatização do sistema previdenciário, colocando a responsabilidade da proteção social nas mãos dos trabalhadores e o gerenciamento dos fundos de pensão com os bancos e instituições financeiras. Porém, a mão invisível do mercado não foi capaz de corresponder às expectativas exigidas para a proteção social, logo esse sistema entrou em crise já no final da década de 1990 e, houve, portanto, uma reestatização das aposentadorias naquele país (MARQUES, 2012).

As críticas em relação à Seguridade Social no Brasil se deram em relação ao questionável déficit das contas da previdência, sempre se afirmou sobre a ingovernabilidade do país tendo em vista o custo da previdência para o governo, e também para o empresariado que, segundo esse famigerado discurso, opera a favor do desemprego, empurrando para a

\footnotetext{
${ }^{4}$ Disponível em: http://elibrary.worldbank.org/content/book/9780821329702. Acessado em 23 set. 2016.
} 
informalidade. Entretanto, não se esclarece que o problema a ser resolvido é de cunho externo à previdência, portanto, além dos benefícios que são pagos. Há a necessidade de crescimento econômico, isso irá gerar sustentabilidade ao sistema; sem a geração de empregos e melhor distribuição de renda, nenhum sistema sobrevive. Assim, Eduardo Fagnani (2008, p. 32) relembra as conquistas históricas da década de 1980 quando se redemocratizou o Brasil e implementaram-se as conquistas sociais na constituinte:

\begin{abstract}
Ignoram que o real pano de fundo para que se compreenda a questão do financiamento da previdência social é o fato de que o Brasil acumula 26 anos de baixo crescimento econômico. Mais precisamente, a partir de meados dos anos 70, no âmago da luta contra a ditadura, o movimento social formulou um amplo projeto de reformas a partir de três núcleos: a restauração do Estado Democrático de Direito; a construção de um sistema de proteção social; e a concepção de uma nova estratégia macroeconômica, direcionada para o crescimento com distribuição de renda [...] Todavia, não avançamos na construção das bases financeiras que dariam sustentação para a cidadania recém conquistada [...] Esse é o pano de fundo para que se compreenda, de fato, qual é a real questão do financiamento da Seguridade Social.
\end{abstract}

Dessa forma, lembra o autor, o problema do desequilíbrio das contas da previdência, como quer o governo e o mercado, tem relação direta com o crescimento dos gastos com benefícios e a "generosidade" do sistema. Porém, ele afirma que a natureza da questão são fatores externos, da política macroeconômica adotada no Brasil nos últimos anos, a qual resultou no baixo crescimento econômico, por consequência, o desemprego e a informalidade, o que ocasiona menos adesão dos trabalhadores ao sistema e a dilapidação das receitas previdenciárias, portanto, "a saída é o crescimento da economia. Sem crescimento não há saídas civilizadas para a Previdência Social - nem para o país” (FAGNANI, 2008, p. 32).

Eduardo Fagnani (2008, p. 34/35) trata das correntes contrárias e fundamentalistas que defendem o Estado mínimo. Para os "seguidores desta corrente", segundo ele, a distribuição de renda entre os mais pobres, ou seja, aqueles que segundo o Banco Mundial estariam abaixo da linha da pobreza, seria a solução, já que essas políticas focalizadas e a escolha pelos mais pobres resolveriam o problema da desigualdade social no Brasil. Entretanto, como explica o autor, essa atuação ideológica das elites tem fim num modelo macroeconômico que busca o 
ajuste fiscal pela "subtração de gastos sociais". As políticas sociais em nosso país, ele ainda explica, possuem dois momentos, o que poderíamos comparar a um gráfico em elevação até a constituinte de 1988 e após a conquista do direito de cidadania consagrada na Carta Política, esse gráfico inverte-se e mostra seu forte declínio com o ataque das políticas liberais dos anos 1990.

A escolha pelas soluções imediatistas e diminutas, como por exemplo, o programa bolsa família, explica, seria uma opção mais interessante para os defensores do Estado mínimo, ao contrário das políticas universais, pois o gasto com o referido programa do Governo Federal "é cerca de R \$ 10 bilhões, enquanto os gastos previdenciários (INSS e Previdência Rural) atingem mais de R\$ 160 bilhões. Esta é a verdadeira razão que move a suposta opção pelos mais pobres”, ensina Fagnani (2008, p. 35). Portanto, estão na agenda do Estado mínimo as políticas paliativas de amenização da extrema pobreza, em detrimento das políticas sociais de abrangência universal e constitucionalmente garantidas.

O conservadorismo brasileiro, ao criticar os direitos sociais introduzidos na Constituição Federal de 1988, apoia-se na ideia de que a carta nasceu velha, que os direitos ali assegurados remontariam a uma época de ouro vivida na Europa do segundo pós-guerra e que se tornou, já em seu alvorecer, uma constituição velha e anacrônica, causando a ingovernabilidade brasileira. A agenda dos governos, desde as décadas de 1990 e 2000, pautou-se pela desconstrução dos direitos sociais apoiados no discurso do déficit nas contas da seguridade e a necessidade do ajuste fiscal para garantir o crescimento econômico. Além de retardarem a legislação infraconstitucional para regulamentar os direitos então estabelecidos em 1988. O primeiro grande "golpe cavalar", na década retrasada, foi a criação da Desvinculação de Recursos da União - DRU, que simplesmente subtraia 20\% (ao ser criada) dos recursos da Seguridade Social. Na época, o plano foi chamado de emergencial. Ainda no governo de Dilma Rousseff, foi enviada a PEC - Proposta de Emenda à Constituição de n. 87/2015, anexada à PEC n. 4/2015 que, ao chegar no Senado, recebeu o número 31/2016, já no atual governo de Michel Temer. Foi então prorrogada até 2023 a vigência da DRU que possibilita, paradoxalmente à ingovernabilidade sem tais recursos, fazer retiradas de quase um terço dos recursos da seguridade, a qual, segundo o próprio governo é deficitária. 


\title{
2. O superávit previdenciário
}

O discurso pautado pelo déficit das contas da previdência social, numa tentativa clara de manipular a opinião popular e garantir as reformas orientadas para o mercado, é o principal mecanismo de convencimento para se alterar a Constituição e a legislação federal. Foi esta uma das maiores justificativas do extinto Ministério da Previdência e Assistência Social, quando se aprovou o regime complementar para o setor público federal, como já mencionamos anteriormente, e agora é o argumento utilizado para implementarem-se reformas no sentido de dificultar a concessão de benefícios. Entretanto, os números apresentados no último fluxograma de caixa do Regime Geral de Previdência Social contrariam as afirmações feitas pelo governo. No acumulado do primeiro semestre de 2015 (dados mais recentes disponibilizados no site oficial), o caixa da previdência social brasileira finalizou com saldo positivo em mais de 7 bilhões de reais somente com os benefícios urbanos $^{5}$.

\begin{abstract}
No acumulado de janeiro a maio de 2015, a arrecadação líquida na área urbana, incluída a arrecadação Comprev, somou R\$ 138,7 bilhões, leve aumento de $0,1 \%$ (+R $\$ 205,2$ milhões), em relação ao mesmo período de 2014 , e a arrecadação rural resultou em $\mathrm{R} \$ 2,8$ bilhões, queda de 5,0\% (-R $\$$ 146,7 milhões). A despesa com benefícios previdenciários urbanos, incluídas as despesas com sentenças judiciais urbanas e Comprev, totalizou $\mathrm{R} \$ 131,5$ bilhões e $\mathrm{R} \$ 38,0$ bilhões para a clientela rural, incluídas as sentenças judiciais rurais. No acumulado de 2015, o meio urbano somou um superávit de $\mathrm{R} \$ 7,2$ bilhões.
\end{abstract}

Este saldo positivo vem se repetindo ao longo dos anos, na medida em que se demonstra a capacidade financeira do sistema previdenciário brasileiro em pagar seus segurados. A repetição enfadonha deste déficit retrata a intenção de se mascarar os verdadeiros números da Seguridade Social no Brasil.

\footnotetext{
${ }^{5}$ Disponível em: http://www.previdencia.gov.br/wp-content/uploads/2016/06/informe_2015.06.pdf. Acessado em 23 set. 2016.
} 


\section{Gráfico 1 - Fluxograma de caixa do INSS (primeiro semestre 2015)}

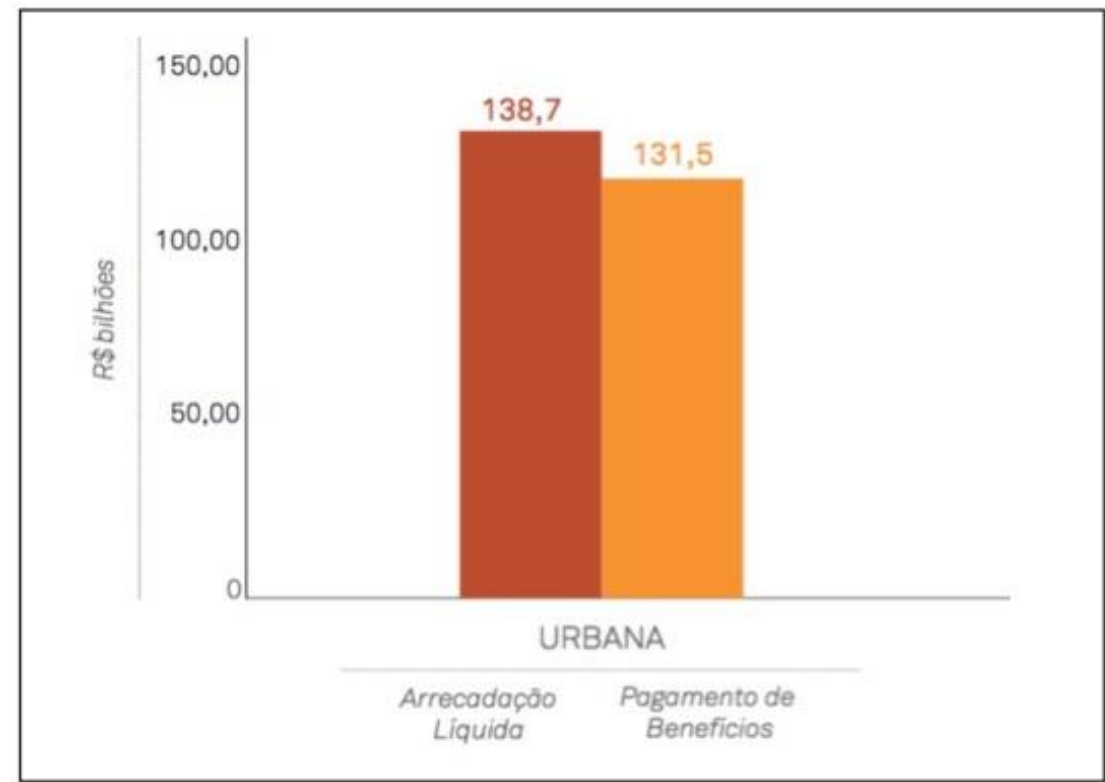

Fonte: Informe Previdência Social - Junho/2015. Volume 27 n. $06^{6}$.

Como podemos ver no gráfico, a diferença entre o que foi arrecadado (líquido) e o que foi pago em benefícios representa um saldo positivo, criando superávit nas contas. Contudo, contrariando a Constituição Federal, em seu art. 195, o qual estipula a estrutura de financiamento da seguridade, a manipulação dos dados se dá no momento em que não se computam todos os recursos que fazem parte desta estrutura de financiamento ao apresentar os dados para a sociedade. Assim, se considera tão somente a receita proveniente das contribuições diretas, subtraindo-se o custo com benefícios, portanto, como afirma Gentil (2006, p. 32), “o resultado é um déficit que não é real”. A mesma autora ainda afirma que, mesmo computando-se a totalidade dos recursos de custeio da previdência, segundo o art. 195 da $\mathrm{CF}$, mesmo que deduzindo as despesas totais, e aqui citamos, gastos administrativos, custeio da dívida e outros gastos que não são previdenciários, teremos um resultado final positivo, ou seja, superavitário. O gráfico acima confirma, mais uma vez, a tese de doutoramento de Gentil (2006). Sobre os gastos não previdenciários, a economista cita que se

${ }^{6}$ Idem

e-ISSN: 2525-9865 | Curitiba | v. 2 | n. 2 | p. 189 - 209 | Jul/Dez. 2016. 
trata dos benefícios pagos pela Assistência Social, por meio de Benefícios de Prestação Continuada da Lei Orgânica da Assistência Social - BPC/LOAS.

É neste cenário que o atual governo trabalha para aprovar no Congresso Nacional a nova reforma da previdência. A investida ideológica é o alto custo do Estado Social que enfraquece a economia do país. Contudo, o discurso para prosseguir com as ações reformistas dos "especialistas" em previdência social é o mesmo, ou seja, que a população brasileira está envelhecendo e vivendo por mais tempo. Assim, a longevidade e a expectativa de vida que refletem positivamente nos índices de desenvolvimento humano, acabam condenando as pessoas a mais tempo de trabalho. Os tecnocratas não aceitam que a vida não deve ser de eterno trabalho e contribuição. O governo e o sistema não aceitam as aposentadorias após 30 e/ou 35 anos de contribuição, principalmente se esta pessoa estiver com idade média inferior a 60 anos.

Inconteste é a informação de que a expectativa de vida dos brasileiros aumentou, entretanto, os mesmos especialistas em previdência social não colocam em pauta ou pelo menos na mesma linha de raciocínio, a crise que o trabalho formal vem sofrendo nas últimas décadas, principalmente após as medidas liberais das décadas de 1970 e 1980. Se, por um lado, o governo age no sentido de dificultar, ou melhor, impedir a concessão de benefícios de aposentadorias e pensões para trabalhadores, por outro, temos um mercado de trabalho altamente excludente, principalmente para pessoas com idade acima dos 40 anos, o que é preconceituoso e paradoxal, visto que não remete, necessariamente, à inserção, neste mesmo mercado, de pessoas mais jovens. Manter pessoas acima de 65 anos de idade no mercado, ainda que homem ou mulher, é no mínimo desleal para com as pessoas de menor idade. A reforma, ao determinar maior tempo na vida laboral, está sendo desumana e pouco estratégica no sentido de manter o aquecimento do próprio mercado de trabalho. As medidas advindas da reforma são cruéis ao passo que exigem mais tempo de contribuição de pessoas que iniciaram a vida laboral muito cedo. Esta é uma das principais propostas da reforma, qual seja, a elevação da idade mínima para ter direito à aposentadoria aos 65 anos, tanto para mulheres quanto para homens, inclusive, igualando a atividade urbana à rural, serviço público ao privado. 
Entretanto, como era de se esperar, a previdência social no Brasil, umas das maiores políticas sociais historicamente constituídas neste país, é responsável pela sobrevivência de milhões de cidadãos que possuem nela seu único meio de subsistência, sendo que direta e indiretamente movimenta a economia de muitos municípios pequenos. Há situações concretas no nordeste brasileiro em que a economia local é sustentada exclusivamente com os benefícios pagos pela previdência social, o que também acaba gerando emprego e renda às pessoas que não estão ligadas diretamente a estes benefícios, seus postos de trabalho são criados em função do giro econômico produzido, sendo que tais afirmações vêm do próprio governo que afirma em artigo $^{7}$ o papel da previdência social dizendo que:

\begin{abstract}
A Previdência Social é um dos principais condicionantes da estabilidade social e do dinamismo econômico no país. O pagamento de benefícios previdenciários equivale a $6 \%$ do PIB nacional, conforme dados de 1998, sendo que este indicador tem sido crescente ao longo dos últimos três anos, como pode ser visto no gráfico1. Na região Nordeste a previdência transferiu recursos da ordem de $9,1 \%$ do PIB regional, sendo que em alguns estados, como Paraíba e o Piauí, as transferências chegaram a 14,2\% e 13,2\% dos respectivos PIBs regionais.
\end{abstract}

A reforma proposta pelo governo é o aumento sistemático na idade e no tempo de contribuição, ao passo que não propõe planos econômicos que garantem a inserção no mercado de trabalho. Por um lado, afirma ser deficitária uma política que comprovadamente possui, ano após anos, saldo positivo em suas contas, por outro, aprova medidas legais para desvincular receita, inclusive, e principalmente, de contribuições sociais para garantir metas orçamentárias. Lembrando que, quando a Constituição "Cidadã” surge no Brasil, num período em que, não somente aqui, mas em toda a América latina, se faziam exigências exógenas de organismos internacionais, a agenda liberal era imposta aos países subdesenvolvidos com forte controle fiscal e orçamentário.

Contudo, atualmente, as medidas tomadas na atual crise rezam a mesma cartilha de austeridades de três décadas atrás. Com isso, o movimento de luta em torno de uma Constituição que garantia direitos universais promulgadas logo após a "reabertura" para a democracia estava às voltas com pressões externas que, naquele momento e nos anos

\footnotetext{
${ }^{7}$ Disponível em: http://www.previdencia.gov.br/arquivos/office/3_081014-104506-380.pdf. Acessado em 25 set. 2016.
} 
seguintes, indicavam caminhos opostos àquelas conquistas, e atualmente é fragmentada e reformada com o objetivo pontual de diminuir gastos públicos.

O discurso é e sempre foi apoiado na generosidade excessiva do sistema e de seu financiamento, já que grande parte dele vem do governo e das empresas empregadoras. Esse discurso é facilmente quebrado já que o custo com previdência social dos trabalhadores nas empresas é considerado gastos com folha de pagamento, como já dito, portanto, tais valores são embutidos no custo de produção que ao final é repassado para o consumidor, e também, que os dados oficiais demonstram a grandiosidade desta política e sua grande capacidade de fazer reservas superavitárias para manter o sistema. Não poderíamos nos pautar em relacionar os mecanismos jurídicos utilizados para reformar a previdência, uma vez que esses já são conhecidos, o objetivo deste estudo foi demonstrar o pano de fundo de uma grande reforma como esta, que se pauta na diminuição de direitos sociais, redução de gastos públicos e formação de grandes fundos que ficam à disposição do governo.

\section{CONSIDERAÇÕES FINAIS}

Os novos rumos, velhos caminhos e as perspectivas para este futuro incerto, parece ser uma realidade para milhões de trabalhadores, não somente no Brasil, mas em todo o mundo. Parece-nos conveniente que o Estado Social, dentro desta perspectiva do "bem-estar" possivelmente esteja ligado intimamente à segurança jurídica que os cidadãos precisam para efetivar suas qualificações na contribuição no avanço da sociedade. Desta forma a sociedade se metamorfoseia, parafraseando Castel (2009), entretanto o pacto estatal corre riscos, pois a investida do capital financeiro avança sobre a principal política de proteção social: a previdência.

Nenhum sistema se mantém pelo simples fato de existir. Assim como é de interesse do modo de produção capitalista, o Estado mínimo para as questões sociais e máximo para as econômicas, é necessária a tomada contínua de consciência para se manterem os direitos sociais já conquistados e avançarmos na efetiva distribuição de renda e na ruptura dos valores políticos contrários ao bem estar geral. É fato, e não podemos negar, que o capital está em 
crise, se a solução foi, há meio século, o pleno emprego e o aumento das condições mínimas para a população nos países que experimentaram o Welfare State, novas soluções deverão surgir para enfrentamento das crises que deixam de ser cíclicas para tornarem-se cada vez mais constantes. Entretanto, a reforma que está em pauta está indo contra o que países desenvolvidos fizeram após a segunda grande guerra, não está formando fundo público para financiamento das Políticas Sociais, está, ao contrário, tomando posse dos fundos já formados para pagar a conta da crise econômica.

No Brasil dos anos 1990 e continuamente nos anos 2000, já no governo intitulado "socialdemocrata", as políticas vêm se retraindo, as rupturas prometidas não somente em campanha, mas pela própria formação do partido político que tomou o governo brasileiro de 2003 a 2016, não foram cumpridas. O poder político se consolida e a austeridade é real, em 2012 foram aprovadas novas medidas de reformas com a imposição de teto para pagamento de benefícios nos sistemas de aposentadorias do setor público brasileiro, pois havia, sem dúvida, grande interesse de organismos privados, principalmente de instituições financeiras, em que os fundos de pensões ou previdência complementar fossem regulamentados, como foi mencionado ao longo deste artigo. Os valores oriundos das contribuições dos servidores migrarão para o mercado especulativo e ficarão sob o domínio dos bancos e financeiras. É a institucionalização, ainda que parcial, da privatização da previdência pública, o início do fim.

Portanto, a reforma que está em pauta irá agravar ainda mais a situação da maioria da população brasileira, que começou sua vida laborativa muito cedo, e será condenada a uma eterna contribuição para um sistema que é autossuficiente, mas por meio de desvinculações orçamentárias garantidas pela Constituição, seu patrimônio é dilapidado e utilizado para outros fins. A necessidade de uma Seguridade Social fortalecida, com benefícios justos e com financiamento público e longe do capital especulativo é um mecanismo importante para se garantir segurança jurídica, dignidade do trabalhador e garantia de renda futura. 


\section{REFERÊNCIAS}

ABRAPP - Associação brasileira das entidades fechadas de previdência complementar. Consolidado estatístico. Disponível em: http://www.abrapp.org.br/Paginas/Home.aspx Acessado em 22 set. 2016.

BANCO MUNDIAL. Averting the Old Age Crisis. Disponível em: http://elibrary.worldbank.org/content/book/9780821329702. Acessado em 23 set. 2016.

BEHRING, Elaine Rossetti, BOSCHETTI, Ivonete. Política Social, fundamentos e história. 2 ed. São Paulo: Cortez, 2007.

BRASIL. Constituição Federal 1988.

CASTEL, Robert. As metamorfoses da questão social: Uma crônica do salário. Trad. Iraci D. Poleti. 8 ed. Petrópolis, RJ: Editora Vozes, 2009.

GENTIL, Denise Lobato. A política fiscal e a falsa crise da seguridade social brasileira análise financeira do período 1990-2005. (tese). Rio de Janeiro: UFRJ, 2006.

MARQUES, Rosa Maria. A experiência inédita de (re)estatização das aposentadorias na Argentina". In. Minicurso no $7^{\circ}$ Encontro Nacional de Política Social/UFES, entre os dias 27 a 29 de junho de 2012 em Vitória - ES

MINAYO, Maria Cecília de Souza.(Org). Pesquisa Social: Teoria, método e criatividade. $2^{\mathrm{a}}$. ed. Petrópolis, RJ: Vozes, 1994.

PREVIDÊNCIA SOCIAL. Disponível em: http://www.previdencia.gov.br/arquivos/office/3_081014-104506-380.pdf. Acessado em 25 set. 2016.

Fluxograma de caixa. Disponível em: http://www.previdencia.gov.br/wp-content/uploads/2016/06/informe_2015.06.pdf. Acessado em 23 set. 2016.

PAULANI, Leda Maria. Seguridade Social, Regimes Previdenciários e Padrão de Acumulação: Uma Nota Teórica e uma Reflexão sobre o Brasil. In FAGNANI, Eduardo. HENRIQUE, Wilnês e LÚCIO, Clemente Ganz. (organizadores). Previdência Social: Como Incluir os Excluídos? Uma agenda voltada para o desenvolvimento econômico com distribuição de renda. São Paulo: LTr, 2008.

SILVA, Marluce A. S. Nem déficit, nem superávit na Seguridade Social: Contra-reforma com retenções, renúncias e suplementações orçamentárias. (tese). Brasília: UnB, 2008.

e-ISSN: 2525-9865 | Curitiba | v. 2 | n. 2 | p. 189 - 209 | Jul/Dez. 2016. 
VARELA, Raquel. $\quad$ Entrevista. $\quad$ Disponível em http://operamundi.uol.com.br/conteudo/entrevistas/25401/capitalismo+e+doente+terminal+lig ado+apenas+nos+cofres+publicos+diz+historiadora+portuguesa+.shtml. Acessado em 20 set. 2016.

VARSANO, Ricardo. Financiamento do Regime Geral de previdência Social no Contexto do Processo de Reforma Tributária em Curso. In MINISTÉRIO DA PREVIDÊNCIA. Base de Financiamento da Previdencia Social: Alternativas e Perspectivas. Vol. 19. Brasília: MPS, 2003. 